\title{
Annual Incidence, Prevalence, and Mortality of Multiple Sclerosis in White South-African-born and in White Immigrants to South Africa*
}

\author{
GEOFFREY DEAN, $\dagger$ M.D., F.R.C.P.
}

On settling in South Africa in 1947 I learned that multiple sclerosis (M.S.), or disseminated sclerosis as it was usually called, was thought to be uncommon among South Africans. I therefore proceeded with a study of all white patients diagnosed as having this disease at the major South African hospitals and found that 14 out of 27 in whom the diagnosis could be accepted as probable in 1948 were immigrants from Europe, though immigrants were only $10 \%$ of the population at risk. Among the South-African born White population the disease was apparently uncommon. ${ }^{1}$

The present study extended from 1958 to 1966. A full account of the methods used for case ascertainment and of the comparative surveys which were made of the healthy population at risk will be published separately. Over the eight years of this study every means possible was sought to discover and investigate patients suspected of having M.S. All the South African physicians and neurologists co-operated in supplying the names and medical histories of patients who might have M.S. The records of the major hospitals were searched. Repeated articles and three editorials appeared in the South African Medical fournal about the survey, also articles in the popular press and radio reports. Personal letters were sent on two occasions to every doctor in practice in South Africa. A Multiple Sclerosis Society was formed, and this helped greatly with publicity and in tracing patients. Every effort was made to see that all cases of possible M.S. were fully investigated by competent neurologists. Ninety-four per cent. of the patients having probable M.S. on prevalence day were also personally examined by me. All death certificates since 1949 in which million of White stock, approximately $1 \frac{1}{2}$ million "Coloured" or of a mixed breed living mainly in the Cape, half a million Asians, mainly Indians in Durban and Natal, and 11 million African or Bantu people. The 3 million White population of South Africa consisted of $1,837,000$ predominantly Afrikaans speaking (Afrikaners) and the remainder were nearly all English-speaking. The Afrikaners are the descendants of Dutch, German, and French Huguenot farmers (the Boers) who settled in South Africa in the seventeenth and eighteenth centuries. The English-speaking South Africans consisted in 1960 of 313,000 immigrants, most of whom were from the United Kingdom and Europe, and 925,000 native-born White South Africans who were descendants of settlers who had arrived from Europe comparatively recently.

The patients investigated were classified as having probable M.S. when there was a multiplicity of lesions in the central nervous system, usually exacerbations and remissions, and the necessary investigations to exclude other pathology had been carried out. If there was any doubt about the diagnosis the patients were classified as having possible M.S. The remainder were classified as not M.S. Over the years most of the possible M.S. cases were reclassified as either probable M.S. or not M.S.

\section{Results of the Survey}

Table I shows the results of the survey when the study was closed. Of the 281 White patients with probable M.S. on prevalence day 1960158 were South-African-born and 123

Table I.-Probable and Possible Multiple Sclerosis Patients on Prevalence Day (Census Day, 1960) and the Populations at Risk

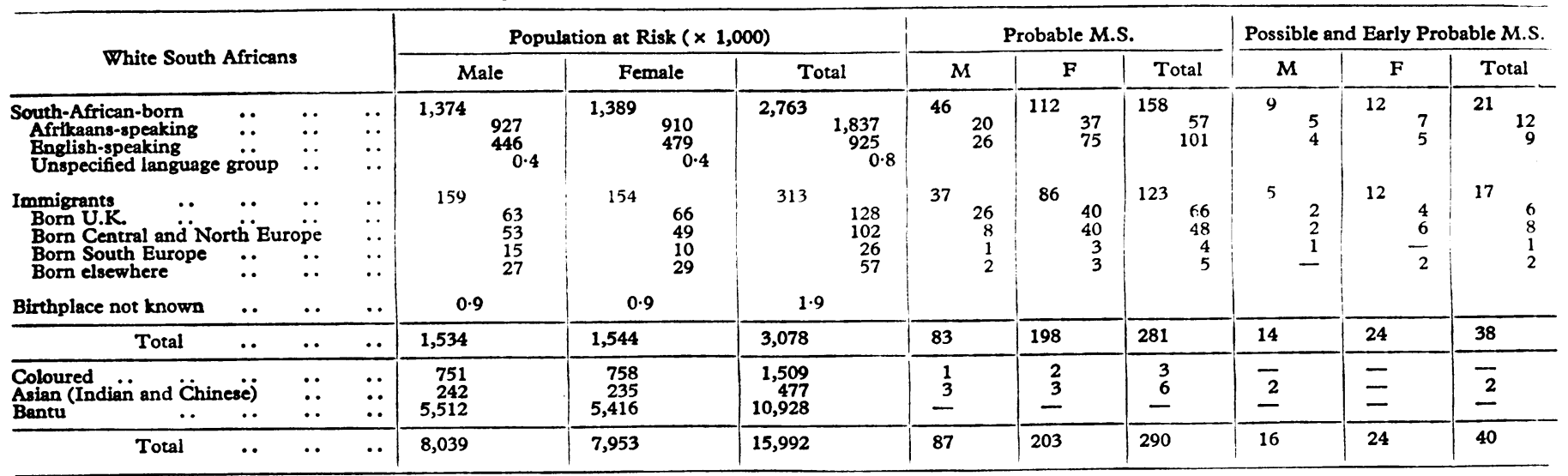

disseminated, or multiple, sclerosis had been mentioned as the primary cause of death, and since 1958 as a primary or a contributory cause of death, were reported by the Registrar of Deaths, Pretoria. If not already available the medical history of these patients was then obtained.

The population of South Africa at the Census in 1960prevalence day in this study-consisted of approximately 3

- This study was supported by Research Grants Nos. 247-1-5 from the National Multiple Sclerosis Society, New York, U.S.A. † Eastern Cape Provincial Hospital, Port Elizabeth, South Africa. were immigrants to South Africa. There is also a high proportion of immigrants among the possible M.S. patients, 17 out of 38. Of the 158 South-African-born M.S. patients, 101 were English-speaking, and a higher proportion of these M.S. cases than of age-standardized controls, from a large market research survey of the population at risk, were first-generation SouthAfrican-born with both parents immigrants from Europe. ${ }^{2}$ The difference between the actual number with both parents born in Europe (40 out of 101) and the "expected" number (23.5) is statistically significant $(P<0.01)$. In a further 22 of the 
101 English-speaking South-African-born M.S. patients the father or the mother had been born in Europe.

Of the 101 English-speaking South-African-born, 46 had visited Europe before prevalence day. As this appeared to be a high proportion a survey of the population at risk was undertaken, when it was found that 40.5 out of 101 controls matched by sex, birthplace, language, and age group, and with the same birthplace of parents, had visited Europe ; this number is not significantly different from that of the M.S. patients. ${ }^{2}$

\section{Annual Incidence of Multiple Sclerosis}

The annual incidence reached its peak during 1945-54, no doubt because a number of cases of probable M.S. after 1955 had not then been diagnosed and reported. The average annual incidence for probable M.S. for all White South Africans for the 10-year period 1945-54, based on the 1951 Census, was $0.6 / 100,000$ both for the South African population and also, when age standardization is made, for the population distribution of England and Wales. For the South-African-born it is 0.4. The Afrikaans-speaking South-African-born have the lowest incidence, 0.2. The English-speaking South-Africanborn rate is four times higher at 0.8 .

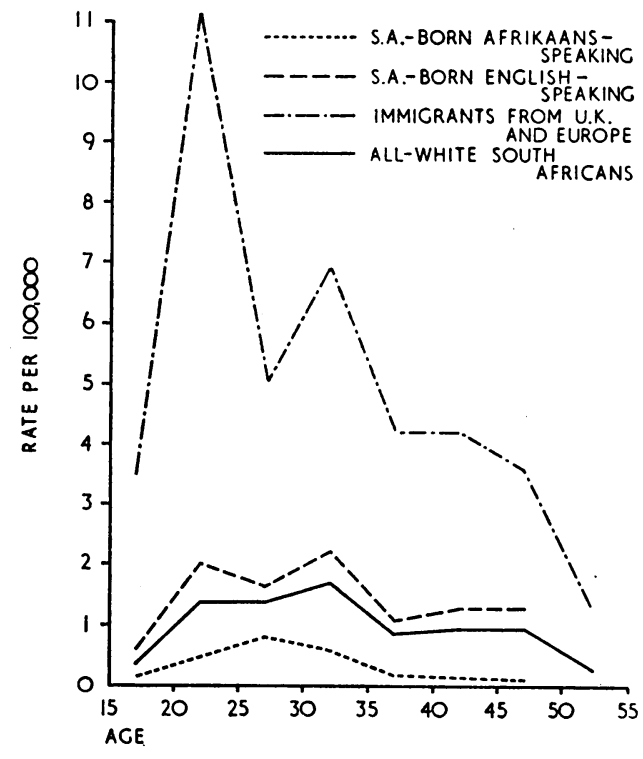

FrG. 1.-Probable M.S. in White South Africans. Average annual incidence, 1945-64. Age at onset of first symptoms (151 patients).
Compared with the South-African-born the average annual incidence for M.S. was high among the immigrants to South Africa, 2.1 per 100,000 . The annual incidence rates, agestandardized to the population distribution of England and Wales, was much higher among immigrants from the United Kingdom (2.8) and Europe (2.9) than among those immigrants who were not born in Europe (0.3) (Fig. 1). The rates found among immigrants from the United Kingdom are the same as that which Allison and Millar ${ }^{3}$ found in Northern Ireland, 2.8 (1951). The female/male incidence ratio was higher than has been found in other studies, particularly for the immigrants from the continent of Europe. ${ }^{4}$

\section{Prevalence of Multiple Sclerosis}

The 281 patients with probable M.S. on prevalence day 1960 make an overall prevalence rate for White South Africans of $9.1 / 100,000$ (males 5.4, females 12.8). The rate is $11 / 100,000$ when age-standardized to the population of England and Wales (Table II).

Among the White South-African-born the prevalence rate/ 100,000 is three and a half times higher for the English-speaking, 10.9/100,000 (12.7 age-standardized to England and Wales), than among the Afrikaans-speaking, 3.1 (3.6 agestandardized to England and Wales). Among the White immigrants the rates are highest for the United Kingdom, 51.4 (40.9 age-standardized to England and Wales), and North and Central Europe, 47.0 (Figs. 2, 3, and 4). These rates are much the same as those reported from the United Kingdom by Pratt et al. ${ }^{6}$ 44/100,000 (1949), and by Hargreaves, 63/100,000 $(1958) .^{5}$ Similar rates have been reported from Holland by Dassel, ${ }^{7}$ 56/100,000 (1960).

Immigrants from Northern and Central Europe have a higher M.S. prevalence rate (47.0) than immigrants from Southern Europe (15.5), though the numbers involved are small. Out of 52 immigrants from Europe four were from Southern Europe and the "expected" number was $11(\mathrm{P}<0.05)$. Immigrants born elsewhere than in Europe had a low prevalence. There were five M.S. patients in this group-a prevalence rate of $8.8 / 100,000$. The difference between the actual number of M.S. cases (5) and the "expected " number (23) is statistically significant $(P<0.01)$. There is considerable variation when the prevalence rates of the immigrants from the different countries of Northern and Central Europe are compared-the number of immigrants with M.S. from each country is, however, small and the variation falls within the expected Poisson distribution.

TABle II.-Prevalence of Probable M.S. among White South Africans, 1960. ' Rates per 100,000

\begin{tabular}{|c|c|c|c|c|c|c|c|c|c|c|c|c|c|}
\hline . & $20-24$ & $25-29$ & $30-34$ & $35-39$ & $40-44$ & $45-49$ & $50-54$ & $55-59$ & $60-64$ & $65+$ & $\begin{array}{l}\text { Total } \\
\text { No. }\end{array}$ & $\begin{array}{c}\text { Rates/ } \\
100,000\end{array}$ & $\begin{array}{l}\text { Age } \\
\text { Correctedto } \\
\text { Population } \\
\text { of England } \\
\text { and Wales }\end{array}$ \\
\hline $\begin{array}{l}\text { Males: } \\
\text { South-African-born ... } \\
\text { Afrikaans-speaking } \\
\text { English-speaking } . \ddot{K} .\end{array}$ & $\begin{array}{l}1 \cdot 8(2) \\
2 \cdot 7(2)\end{array}$ & $\begin{array}{l}3 \cdot 2(3) \\
1 \cdot 6(1) \\
7 \cdot 1(2)\end{array}$ & $\begin{array}{l}5 \cdot 4(5) \\
4 \cdot 8(3) \\
6 \cdot 8(2)\end{array}$ & $\begin{array}{l}7 \cdot 1(6) \\
7 \cdot 1(4) \\
7 \cdot 0(2)\end{array}$ & $\begin{array}{c}12.6(10) \\
5.7(3) \\
26.1(7)\end{array}$ & $\begin{array}{c}14 \cdot 1 \text { (11) } \\
8 \cdot 1(4) \\
25 \cdot 0(7)\end{array}$ & $\begin{array}{r}7 \cdot 2(5) \\
2 \cdot 2(1) \\
16 \cdot 2(4)\end{array}$ & $\begin{array}{l}4.2(2) \\
3.2(1) \\
6.0(1)\end{array}$ & $\begin{array}{l}5 \cdot 9(2) \\
4 \cdot 2(1) \\
9 \cdot 4(1)\end{array}$ & $=$ & $\begin{array}{l}46 \\
20 \\
26\end{array}$ & $\begin{array}{l}3 \cdot 3 \\
2 \cdot 1 \\
5 \cdot 8\end{array}$ & $\begin{array}{l}4 \cdot 1 \\
2 \cdot 8 \\
6 \cdot 8\end{array}$ \\
\hline All White South Africans & $1 \cdot \overline{7(2)}$ & $\begin{array}{l}11 \cdot 3(1) \\
3 \cdot 8(4)\end{array}$ & $4 \cdot \overline{8(5)}$ & $\begin{array}{l}9 \cdot 0(1) \\
8 \cdot 1(8)\end{array}$ & $\begin{array}{l}62 \cdot 0(7) \\
18 \cdot 4(17)\end{array}$ & $\begin{array}{l}46 \cdot 1(6) \\
18 \cdot 4(17)\end{array}$ & $\begin{array}{l}57 \cdot 5(8) \\
15 \cdot 4(13)\end{array}$ & $\begin{array}{l}54 \cdot 4(6) \\
13 \cdot 4(8)\end{array}$ & $\begin{array}{r}11 \cdot 2(1) \\
6 \cdot 8(3)\end{array}$ & $\begin{array}{r}22 \cdot 1(5) \\
6.6(6)\end{array}$ & $\begin{array}{l}35 \\
83\end{array}$ & $\begin{array}{r}26 \cdot 6 \\
5 \cdot 4\end{array}$ & $\begin{array}{r}18 \cdot 9 \\
6 \cdot 6\end{array}$ \\
\hline $\begin{array}{l}\text { Females: } \\
\text { South-African-born ... } \\
\text { Afrikaans-speaking } \\
\text { English-speaking } . \ddot{K} . \\
\text { Immigrants from U. }\end{array}$ & $\begin{array}{l}8 \cdot 3(9) \\
9 \cdot 5(7) \\
5 \cdot 8(2)\end{array}$ & $\begin{array}{r}8.5(8) \\
1.6(1) \\
23 \cdot 3(7)\end{array}$ & $\begin{array}{c}16 \cdot 1(15) \\
4 \cdot 8(3) \\
38 \cdot 6(12)\end{array}$ & $\begin{array}{l}20 \cdot 0(17) \\
20 \cdot 3(11) \\
19 \cdot 6(6)\end{array}$ & $\begin{array}{l}22 \cdot 3(18) \\
14 \cdot 0(7) \\
36 \cdot 1 \text { (11) }\end{array}$ & $\begin{array}{c}27 \cdot 1(22) \\
4 \cdot 1(2) \\
61 \cdot 3(20)\end{array}$ & $\begin{array}{c}13.8(10) \\
4.5(2) \\
28.1(8)\end{array}$ & $\begin{array}{r}12.0(6) \\
6.6(2) \\
20.4(4)\end{array}$ & $\begin{array}{r}7 \cdot 6(3) \\
4 \cdot 1(1) \\
13 \cdot 3(2)\end{array}$ & $\begin{array}{r}4 \cdot 6(4) \\
1 \cdot 8(1) \\
10 \cdot 1(3)\end{array}$ & $\begin{array}{r}112 \\
37 \\
75\end{array}$ & $\begin{array}{r}8 \cdot 0 \\
4 \cdot 1 \\
15 \cdot 6\end{array}$ & $\begin{array}{r}9.6 \\
4.8 \\
17.6\end{array}$ \\
\hline $\begin{array}{l}\text { and Europe } \\
\text { All White South Africans }\end{array}$ & $\begin{array}{r}38 \cdot 8(2) \\
9 \cdot 5(11)\end{array}$ & $\begin{array}{r}30 \cdot 5(2) \\
9 \cdot 7(10)\end{array}$ & $\begin{array}{l}68 \cdot 8(6) \\
20 \cdot 0(21)\end{array}$ & $\begin{array}{r}125 \cdot 2(13) \\
30.7(30)\end{array}$ & $\begin{array}{r}120.8(11) \\
31.6(29)\end{array}$ & $\begin{array}{r}118 \cdot 1(13) \\
37 \cdot 2(35)\end{array}$ & $\begin{array}{r}122 \cdot 6(13) \\
28 \cdot 4(24)\end{array}$ & $\begin{array}{l}91 \cdot 9(10) \\
25 \cdot 8(16)\end{array}$ & $\begin{array}{l}86 \cdot 8(9) \\
25 \cdot 5(13)\end{array}$ & $\begin{array}{r}14 \cdot 4(4) \\
7.7(9)\end{array}$ & $\begin{array}{r}83 \\
198 \\
\end{array}$ & $\begin{array}{l}66 \cdot 5 \\
12 \cdot 8\end{array}$ & $\begin{array}{l}54 \cdot 5 \\
15 \cdot 4\end{array}$ \\
\hline $\begin{array}{l}\text { Total: } \\
\text { South-African-born .. } \\
\text { Afrikaans-speaking } \\
\text { English-speaking } \\
\text { Immigrants from U.K. }\end{array}$ & $\begin{array}{l}5 \cdot 0(11) \\
6 \cdot 0(9) \\
2 \cdot 9(2)\end{array}$ & $\begin{array}{c}5.9(11) \\
1.5(2) \\
15.4(9)\end{array}$ & $\begin{array}{c}10 \cdot 8(20) \\
4.8(6) \\
23.1(14)\end{array}$ & $\begin{array}{l}13.5(23) \\
13.5(15) \\
13.5(8)\end{array}$ & $\begin{array}{r}17.5(28) \\
9.7(10) \\
31.5(18)\end{array}$ & $\begin{array}{c}20 \cdot 8(33) \\
6 \cdot 1(6) \\
44 \cdot 5(27)\end{array}$ & $\begin{array}{r}10.6(15) \\
3.4(3) \\
22.6(12)\end{array}$ & $\begin{array}{r}8 \cdot 2(8) \\
4.9(3) \\
13.7(5)\end{array}$ & $\begin{array}{r}6 \cdot 8(5) \\
4 \cdot 2(2) \\
11 \cdot 7(3)\end{array}$ & $\begin{array}{l}2.6(4) \\
0.9(1) \\
6.6(3)\end{array}$ & $\begin{array}{r}158 \\
57 \\
101\end{array}$ & $\begin{array}{r}5.7 \\
3.1 \\
10.9\end{array}$ & $\begin{array}{r}6.9 \\
3.6 \\
12.7\end{array}$ \\
\hline All White South Africans & $\begin{array}{r}17 \cdot 6(2) \\
5 \cdot 5(13)\end{array}$ & $\begin{array}{r}19 \cdot 5(3) \\
6.8(14)\end{array}$ & $\begin{array}{l}33 \cdot 5(6) \\
12 \cdot 4(26)\end{array}$ & $\begin{array}{l}65 \cdot 1(14) \\
19 \cdot 4(38)\end{array}$ & $\begin{array}{l}88 \cdot 3(18) \\
25 \cdot 0(46)\end{array}$ & $\begin{array}{l}79 \cdot 1(19) \\
27 \cdot 9(52)\end{array}$ & $\begin{array}{l}85 \cdot 7(21) \\
21.9(37)\end{array}$ & $\begin{array}{l}73 \cdot 0(16) \\
19 \cdot 7(24)\end{array}$ & $\begin{array}{l}51 \cdot 8(10) \\
16.9(16)\end{array}$ & $\begin{array}{c}17 \cdot 8(9) \\
7 \cdot 2(15)\end{array}$ & $\begin{array}{l}118 \\
281 *\end{array}$ & $\begin{array}{r}46 \cdot 1 \\
9 \cdot 1\end{array}$ & $\begin{array}{l}36 \cdot 0 \\
11 \cdot 0\end{array}$ \\
\hline
\end{tabular}


The mean age at onset for all White South Africans was 31 years. The immigrants, an older population, had a mean age at onset of 33 years, the English-speaking South-African-born 31 years, and the Afrikaans-speaking 27 years. The mean period from onset to diagnosis was eight years and from diagnosis to prevalence day six years.

\section{Female : Male Ratio}

Among the immigrants from the United Kingdom the female : male ratio of $1.6: 1$ for the populations at risk is much the same as has been found in other studies. The average according to Acheson ${ }^{4}$ is $1.4: 1$. Among 69,000 male immigrants

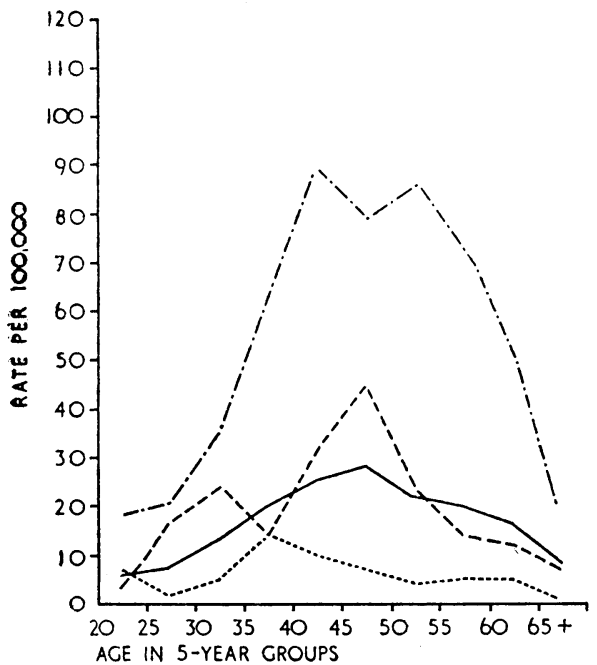

FIG. 2

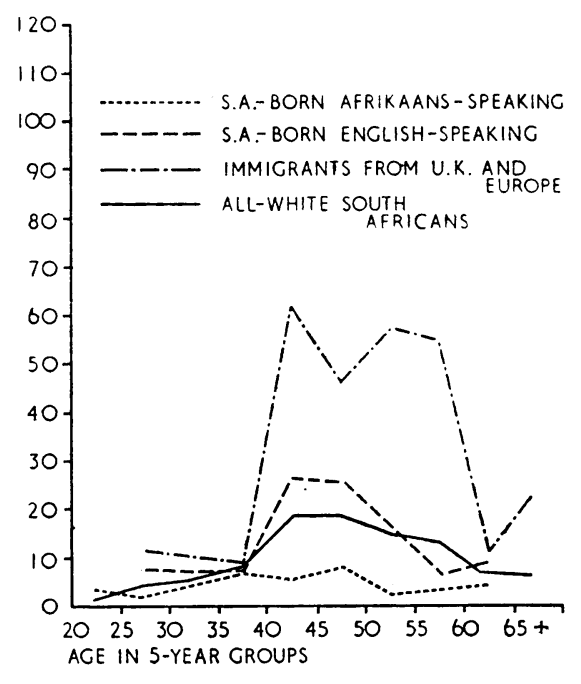

FIG. 3

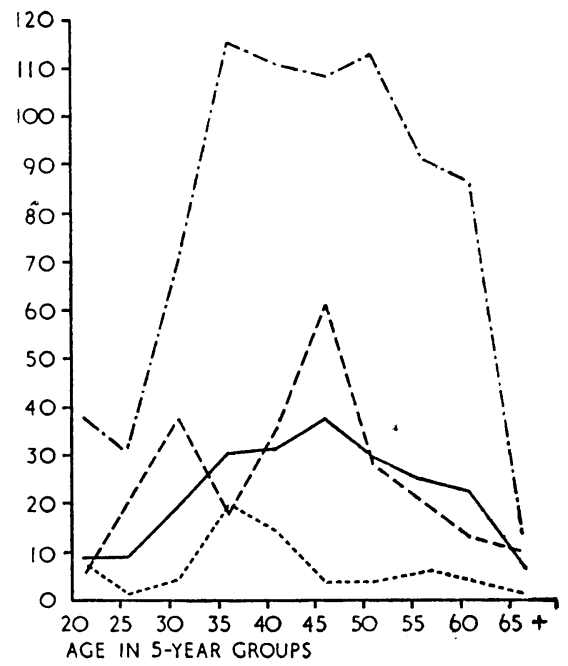

FIG. 4

F1G. 2.-Probable M.S. in White South Africans. Prevalence rates, 1960. Fig. 3.-Probable M.S. in White South Africans. Male prevalence rates, 1960. FIG. 4.-Probable M.S. in White South Africans. Female prevalence rates, 1960.

Table III.-Prevalence Rates/100,000 on Prevalence Day, 1960. White Patients with Probable Multiple Sclerosis. Cities, Other Urban and Rural Areas

\begin{tabular}{|c|c|c|c|c|c|c|c|c|c|c|c|c|}
\hline & \multicolumn{4}{|c|}{ Four Largest Cities } & \multicolumn{4}{|c|}{ Other Urban Areas } & \multicolumn{4}{|c|}{ Rural Areas } \\
\hline & Male & Female & Total & $\begin{array}{c}\text { No. of } \\
\text { Patients }\end{array}$ & Male & Female & Total & $\begin{array}{c}\text { No. of } \\
\text { Patients }\end{array}$ & Male & Female & Total & $\begin{array}{l}\text { No. of } \\
\text { Patients }\end{array}$ \\
\hline $\begin{array}{ll}\text { Bouth-African-born } & \ldots \\
\text { Afrikaans-speaking } & \ldots \\
\text { Bnglish-speaking } & \ldots \\
\text { Buropean immigrants } & \text { to } \\
\text { South Africa .. } & \ldots \\
\text { Immigrants to South Africa }\end{array}$ & $\begin{array}{ll}3 & \\
& 1 \\
& 5\end{array}$ & $\begin{array}{rr}13 & 6 \\
& 18\end{array}$ & \begin{tabular}{|rr}
8 & \\
& 4 \\
& 12
\end{tabular} & $\begin{array}{l}75 \\
15 \\
60 \\
76 \\
80\end{array}$ & 3 & $\begin{array}{rr}6 & 4 \\
& 11\end{array}$ & 4 & $\begin{array}{l}59 \\
28 \\
31 \\
37 \\
38\end{array}$ & $\begin{array}{rr}4 & 3 \\
12\end{array}$ & $\begin{array}{rr}6 & 3 \\
& 19\end{array}$ & $\begin{array}{rr}5 & 3 \\
16 \\
26 *\end{array}$ & $\begin{array}{l}24 \\
14 \\
10 \\
5 \\
5\end{array}$ \\
\hline All White South Africans & 7 & 21 & 14 & 155 & 5 & 9 & 7 & 97 & 4 & 7 & 6 & 29 \\
\hline
\end{tabular}

\begin{tabular}{|c|c|c|c|c|c|c|c|c|}
\hline \multirow[t]{2}{*}{, } & \multicolumn{4}{|c|}{ All Urban Areas } & \multicolumn{4}{|c|}{ Rural Areas } \\
\hline & Male & Female & Total & $\begin{array}{l}\text { No. of } \\
\text { Patients }\end{array}$ & Male & Female & Total & $\begin{array}{l}\text { No. of } \\
\text { Patienty }\end{array}$ \\
\hline $\begin{array}{l}\text { Immigrants to South Africa } \\
\text { Immigrants to South Africa from Europe and U.K. only }\end{array}$ & 24 & $\begin{array}{l}57 \\
64\end{array}$ & $\begin{array}{l}40 \\
45\end{array}$ & 118 & $\begin{array}{l}10 \\
13\end{array}$ & $\begin{array}{l}43 \\
58\end{array}$ & 26 & 5 \\
\hline
\end{tabular}

Table IV.-Prevalence Rates $/ 100,000$ on Prevalence Day, 1960. White Patients with Probable Multiple Sclerosis in the Pour Provinces of South Africa

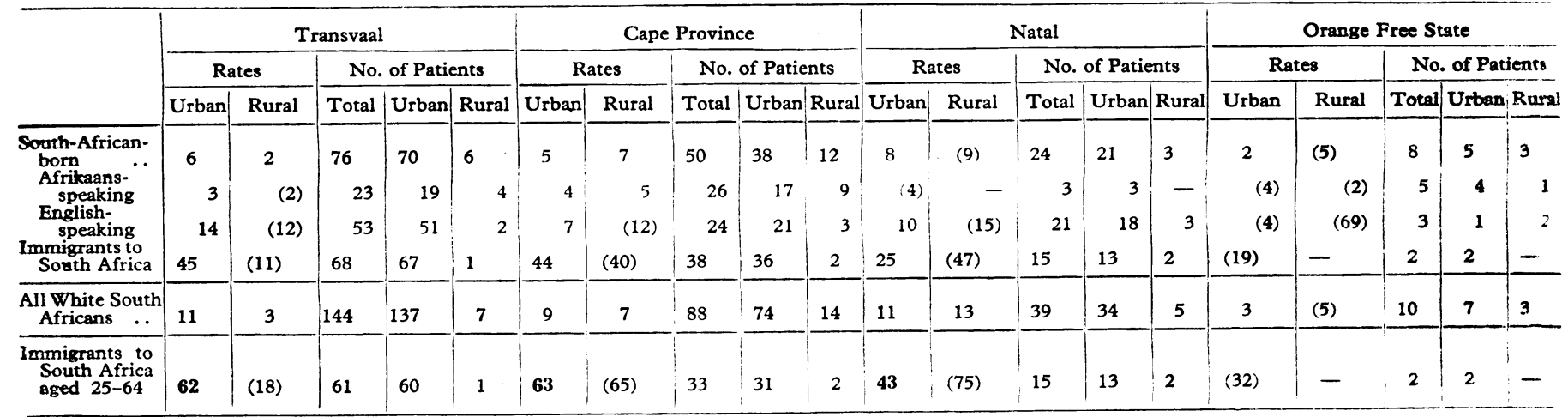

Figures in parentheses indicate that the number of M.S. patients is less than 5 . The Urban Natal rate for immigrants is depressed by the fact that there are a large number of immigrants (22\%) over the age of 65 with a low M.S. prevalence 10
Nater Netal compared with the Cape (18\%) or Transvaal (12\%). Below the age of 65 the immigrant population of Natal is also "older than 
from the continent of Europe there were only nine M.S. patients and among 59,000 female immigrants there were 43 with M.S. The Registrar-General of England and Wales, ${ }^{8}$ Miller et al.,9 and Beebe et al. ${ }^{10}$ have reported that M.S. is more frequent in the higher social class, and male immigrants from Continental Europe are very often unskilled single men, unlike most of the male immigrants from the United Kingdom. Unskilled men would not be likely to emigrate if they already had symptoms of M.S. Some other factor, not at the moment apparent, may be responsible for the high female:male ratio among the immigrants from the Continent of Europe.

Among the Afrikaans-speaking South-African-born the sex ratio $1.8: 1$ is not significantly different from the expected ratio; among the English-speaking South-African-born the sex ratio is higher than expected-2.7:1.

No difference between urban and rural areas was found in South Africa (Table III) ${ }^{11-13}$ nor was any significant difference found for the various groups of White South Africans among the four provinces, that is between the temperate Cape, the highveld Transvaal, or subtropical Natal (Table IV). The high prevalence of M.S. among immigrants from the United Kingdom and Northern Europe is still very apparent if only those patients are considered who had their first symptom after leaving Europe (72 out of 118).

\section{Annual Mortality from Multiple Sclerosis}

During 1960-4 M.S. was given as the primary cause of death on the death certificate of 29 patients, but on review only 18 of them could be accepted as having probable M.S. These 18 deaths represent $34 \%$ of the 53 from probable M.S. during these years. During the present study deaths concerning which M.S. was mentioned as a contributory cause have been reported to me by the Registrar of Deaths; there were 17 deaths in this group during $1960-4$, and in 14 of them the diagnosis on review was regarded as probable-that is, $26 \%$ of the 53 deaths. A further 21 deaths occurred in patients who during their lifetime, and on review in this study, were thought to have probable M.S.; but no mention of the disease was made on the death certificates-that is, $40 \%$ of the 53 deaths (Table V).

For all White South Africans the annual average number of deaths from M.S. in 1960-4 was 10.6-giving an average anmual mortality rate of 0.4 per 100,000 White South Africans at risk ( 0.2 for men and 0.5 for women). For the South-African-born the annual average mortality rate was 0.2 ( 0.1 for men, 0.3 for women). The annual average mortality rate was 0.1 for the Afrikaans-speaking and 0.4 for the English-speaking White South-African-born. Among White immigrants from Europe to South Africa the average annual mortality rate for 1960-4 was 1.7 (men 1.1, women 2.4). It must be remembered that the South African White population doubled between 1921 and 1960 and that the M.S. mortality rates are based on a population who on average developed M.S. many years earlier.

For all White South African M.S. deaths the mean age at onset of M.S. was 31 years and the mean age at death 51 , giving a minimum average duration of the disease of 20 years for those who have died-some mild cases may have been overlooked. The mean age of death of the South-African-born, 47 years, is lower than the mean age of death of the immigrants (53 years), but the immigrants are an older population with more M.S. cases of milder type who developed the disease at an older age. The highest mortality rate for White South African M.S. patients was in the age group 60-64 (Fig. 5).

Necropsy confirmation of M.S. in White South-African-born patients who had never been outside South Africa has already been reported on three patients living in the Transvaal, the Orange Free State, and the Cape (1965),1415 and a further case has been histologically confirmed since then. As yet there has

TABLE V.-Reported and Calculated Mortality from M.S. among White South Africans

\begin{tabular}{|c|c|c|c|c|c|c|c|c|c|c|c|c|c|c|c|c|c|c|c|c|c|c|}
\hline \multirow{3}{*}{$\begin{array}{l}\text { Year } \\
\text { (1) }\end{array}$} & \multirow{2}{*}{\multicolumn{2}{|c|}{$\begin{array}{c}\text { Reported by } \\
\text { Bureau of } \\
\text { Statistics } \\
\text { as Primary } \\
\text { Cause of } \\
\text { Death } \\
\text { (2) } \\
\end{array}$}} & \multirow{2}{*}{\multicolumn{2}{|c|}{$\begin{array}{c}\text { M.S. } \\
\text { Primary } \\
\text { Cause on } \\
\text { Death } \\
\text { Certificate } \\
(3) \\
\end{array}$}} & \multicolumn{6}{|c|}{$\begin{array}{l}\text { Final Diagnosis of } \\
\text { these Cases }\end{array}$} & \multirow{2}{*}{\multicolumn{2}{|c|}{$\begin{array}{c}\text { Additional: } \\
\text { M.S. } \\
\text { Contributing } \\
\text { Cause on } \\
\text { Death } \\
\text { Certificate } \\
\text { (7) } \\
\end{array}$}} & \multicolumn{6}{|c|}{$\begin{array}{l}\text { Final Diagnosis of } \\
\text { these Cases }\end{array}$} & \multirow{2}{*}{\multicolumn{2}{|c|}{$\begin{array}{c}\text { Additional: } \\
\text { M.S. } \\
\text { but not } \\
\text { Mentioned } \\
\text { on Death } \\
\text { Certificate } \\
\text { (11) }\end{array}$}} & \multirow{2}{*}{\multicolumn{2}{|c|}{$\begin{array}{c}\text { Pinal } \\
\text { Count of } \\
\text { Probeblo } \\
\text { M.S. } \\
\text { (12) }\end{array}$}} \\
\hline & & & & & \multicolumn{2}{|c|}{$\begin{array}{c}\text { M.S. } \\
\text { (4) }\end{array}$} & \multicolumn{2}{|c|}{$\begin{array}{c}\text { Doubtful } \\
(5)\end{array}$} & \multicolumn{2}{|c|}{$\begin{array}{c}\text { Not M.S. } \\
(6)\end{array}$} & & & \multicolumn{2}{|c|}{ M.S. } & \multicolumn{2}{|c|}{$\begin{array}{l}\text { Doubtful } \\
(9)\end{array}$} & \multicolumn{2}{|c|}{$\begin{array}{l}\text { Not M.S. } \\
(10)\end{array}$} & & & & \\
\hline & $\mathbf{M}$ & $\mathbf{F}$ & $\mathbf{M}$ & $\mathbf{F}$ & $\mathbf{M}$ & $\mathbf{F}$ & $\mathbf{M}$ & $\mathbf{F}$ & $\mathbf{M}$ & F & $M$ & $F$ & $M$ & $\mathbf{F}$ & M I & $\mathbf{F}$ & $\mathbf{M}$ & F & $M$ & $\mathbf{F}$ & $\mathbf{M}$ & F \\
\hline
\end{tabular}

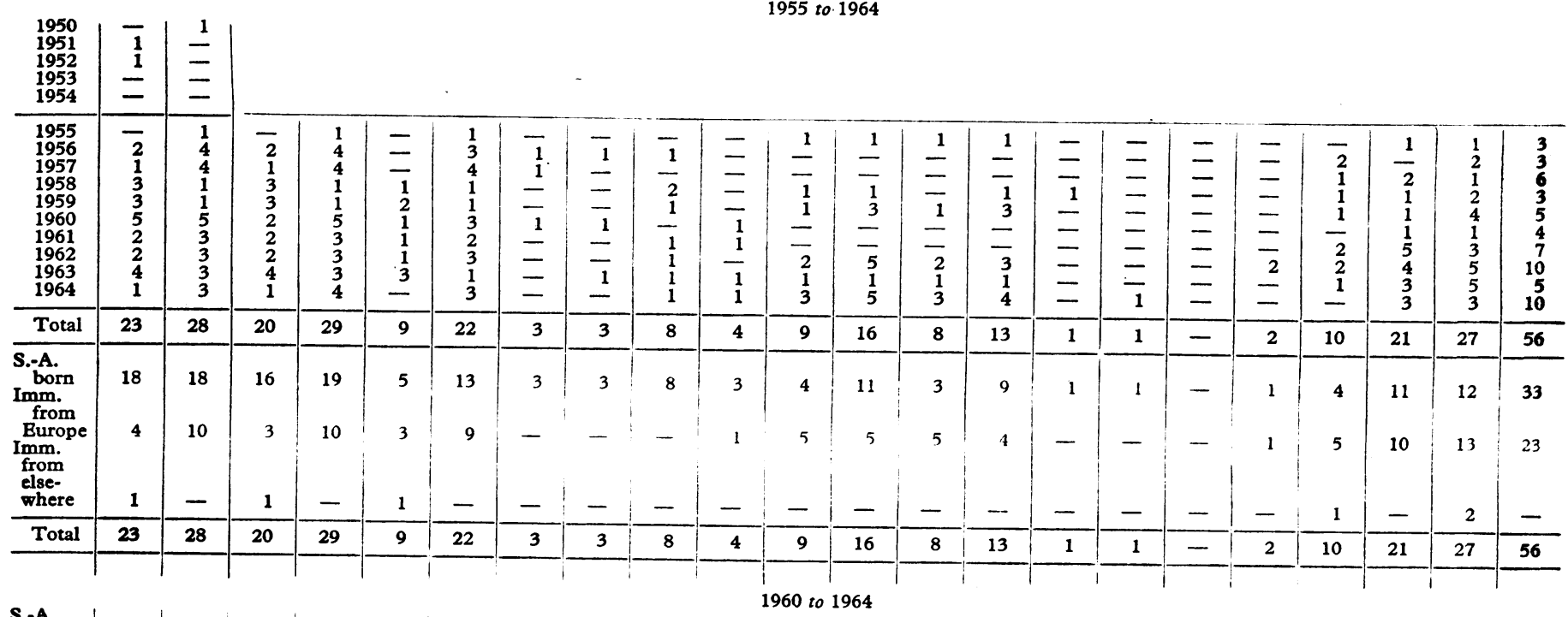

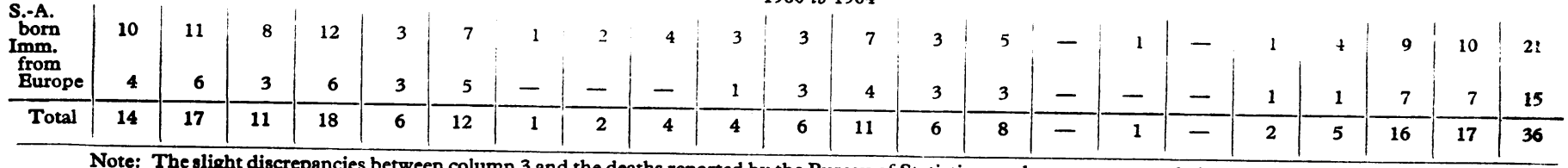


not been necropsy confirmation of M.S. in a South African Coloured, Asian, or Bantu. ${ }^{16-18}$

Though there is no evidence of direct inheritance of M.S. in South Africa the probability of two members of the same family developing M.S. has occurred, both among immigrants and the South-African-born, more frequently than would be expected by chance alone. Three of the White South-Africanborn had a brother or sister who had M.S., and in three of the White immigrants M.S. occurred in another member of the immediate family. Among the Indian patients two women with M.S. were second cousins and one Indian man with M.S. had

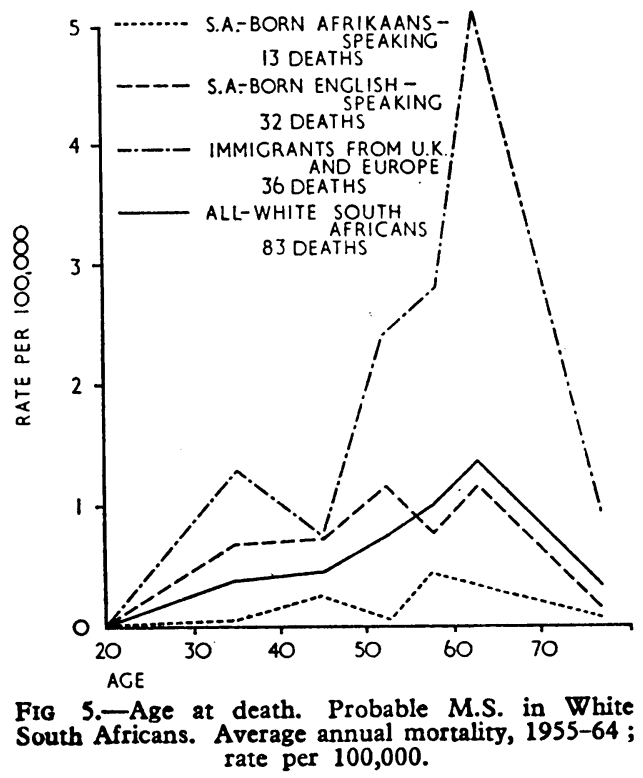

a brother who had had two attacks of retrobulbar neuritis. Three of the White M.S. patients were doctors, one of whom died just before prevalence day, and two of the women M.S. patients were doctors' wives. Of the 101 English-speaking South-African-born White M.S. patients, 16 were of the Jewish faith.

There is little discernible difference in the distribution of economic class between the M.S. patients and the population at risk, English-speaking and Afrikaans-speaking. In one sense the big difference between the English- and Afrikaans-speaking prevalence rates is a social-class one, but it appears to be a difference in way of life rather than a question of poverty- there are very few poor White people in South Africa in the European sense of the word. However, on the whole the English-speaking population, especially in the urban areas, enjoy a higher standard of living than the Afrikaans-speaking.

\section{Discussion}

The epidemiological findings in South Africa-summarized in Table VI-must be considered in conjunction with the epidemiological studies carried out elsewhere in the world. Alter et al. ${ }^{19}$ reported a high prevalence of M.S. among Jewish immigrants to Israel from Northern Europe and a low prevalence among the Israeli-born. Kurland ${ }^{20}$ and Westlund and Kurland ${ }^{21}$ found that the prevalence of M.S. was three times higher in Winnipeg than in New Orleans. In Australia the M.S. rate is apparently fairly high both for the immigrants from Europe and for the Australian-born White population. ${ }^{2-24}$ The rate increases from North to South Australia and is highest in Tasmania. The rate is apparently higher in New Zealand than in South Australia. ${ }^{4}$ In Japan ${ }^{25}$ M.S. is uncommon, and apparently so in South America. It has been reported to be commoner in the higher social classes in the United Kingdom and the United States. ${ }^{8-10}$

An environmental factor would appear to be mainly responsible for M.S., and this environmental influence may be associated to some extent with latitude. Barlow ${ }^{26}$ believes that geomagnetic latitude has a closer correlation with the frequency of M.S. than has geographic latitude. Nevertheless, M.S. does not accord well the hypothesis that it is due to direct action of climate on the body in the same sense that frostbite or cancer of the skin is directly related to climate. For instance, the coldness of winter is closely related to the distance from the ocean, but this is not correlated with the prevalence of M.S. Swank ${ }^{27}$ has suggested that M.S. is related to consumption of large quantities of animal fat deficient in unsaturated fatty acids. That this is unlikely to be true can be shown in South Africa, where there is a very low prevalence of M.S. among the White South-African-born, who eat a diet rich in animal fat and have a very high death rate from coronary thrombosis.

It has been suggested that a lack of certain trace elements in the food may be responsible for M.S. ; for instance, copper deficiency can cause a demyelinating disease in sheep, swayback disease; and four workers in swayback disease apparently developed an M.S.-like syndrome. ${ }^{28}$ But copper does not protect against exacerbations of M.S.

What theory, then, best fits the epidemiological facts ? In my opinion the most likely is that M.S. is normally an infection

\begin{tabular}{|c|c|c|c|c|c|c|c|c|c|c|c|c|c|c|c|c|}
\hline & \multicolumn{6}{|c|}{ Average Annual Incidence 1951 Census } & \multicolumn{7}{|c|}{ Prevalence Rates 1960 Census } & \multirow{2}{*}{\multicolumn{3}{|c|}{$\begin{array}{c}\text { Average Annual } \\
\text { Mortality } \\
1960 \text { Census } \\
\end{array}$}} \\
\hline & \multicolumn{3}{|c|}{$\begin{array}{c}\text { Not Age } \\
\text { Standardized }\end{array}$} & \multicolumn{3}{|c|}{$\begin{array}{l}\text { Age Standardized } \\
\text { to U.K. }\end{array}$} & \multicolumn{3}{|c|}{$\begin{array}{l}\text { Not Age } \\
\text { Standardized }\end{array}$} & \multicolumn{4}{|c|}{$\begin{array}{l}\text { Age Standardized } \\
\text { to U.K. }\end{array}$} & & & \\
\hline & $\mathbf{M}$ & $\mathbf{F}$ & Total & $\mathbf{M}$ & $\mathbf{F}$ & Total & $\mathbf{M}$ & $\mathbf{F}$ & Total & $\mathbf{M}$ & $\mathbf{F}$ & Total & Ratio & $\mathbf{M}$ & $\mathbf{F}$ & $\begin{array}{c}\text { Total } \\
(1960-4)\end{array}$ \\
\hline 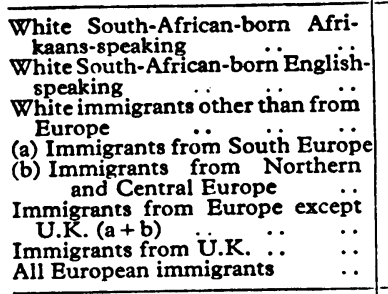 & $\begin{array}{l}0.1 \\
0.4 \\
= \\
- \\
0.9 \\
1.3 \\
1.2\end{array}$ & $\begin{array}{l}0.2 \\
1.1 \\
- \\
- \\
4.5 \\
3.4 \\
3.8\end{array}$ & $\begin{array}{l}0.2 \\
0.8 \\
0.2 \\
- \\
- \\
2.6 \\
2.3 \\
2.4 \\
\end{array}$ & $\begin{array}{l}0.1 \\
0.4 \\
= \\
- \\
1.0 \\
1.3 \\
1.2 \\
\end{array}$ & $\begin{array}{l}0.3 \\
0.9 \\
- \\
- \\
- \\
5.0 \\
4.7 \\
4.6 \\
\end{array}$ & $\begin{array}{l}0.2 \\
0.7 \\
0.3 \\
- \\
- \\
2.9 \\
2.8 \\
2.8 \\
\end{array}$ & $\begin{array}{r}2.1 \\
5.8 \\
7.3 \\
6.4 \\
15.0 \\
13.1 \\
41.5 \\
26.6 \\
\end{array}$ & $\begin{array}{r}4 \cdot 1 \\
15 \cdot 7 \\
10 \cdot 2 \\
29 \cdot 0 \\
82 \cdot 1 \\
72 \cdot 8 \\
60.9 \\
66 \cdot 6 \\
\end{array}$ & $\begin{array}{r}3.1 \\
10.9 \\
8.8 \\
15.5 \\
47.0 \\
40.6 \\
51.4 \\
46.1 \\
\end{array}$ & $\begin{array}{c}2.8 \\
5.8 \\
7.9 \\
- \\
- \\
10.0 \\
27.7 \\
18.9 \\
\end{array}$ & $\begin{array}{r}4.8 \\
15.7 \\
14.8 \\
- \\
- \\
58.1 \\
52.7 \\
54.5 \\
\end{array}$ & $\begin{array}{r}3.6 \\
12.7 \\
11.6 \\
- \\
- \\
32.3 \\
40.9 \\
36.0 \\
\end{array}$ & $\begin{array}{l}11 \cdot 1 \\
10\end{array}$ & $\begin{array}{l}- \\
- \\
= \\
-\end{array}$ & $\begin{array}{l}- \\
- \\
- \\
-\end{array}$ & $\begin{array}{l}0.1 \\
0.4 \\
= \\
-\end{array}$ \\
\hline All South-African-born .. & $0 \cdot 2$ & 0.5 & 0.4 & $0 \cdot 2$ & 0.5 & 0.4 & $3 \cdot 3$ & $8 \cdot 1$ & $5 \cdot 7$ & $4 \cdot 1$ & $9 \cdot 6$ & 6.9 & & $0 \cdot 1$ & 0.3 & $0 \cdot 2$ \\
\hline All White South Africans & 0.3 & 0.8 & 0.6 & $0 \cdot 3$ & 0.8 & 0.6 & $5 \cdot 4$ & $12 \cdot 8$ & $9 \cdot 1$ & 6.6 & $15 \cdot 4$ & $11 \cdot 0$ & & $0 \cdot 2$ & 0.5 & $\begin{array}{c}0.4 \\
(0.36)\end{array}$ \\
\hline $\begin{array}{l}\begin{array}{l}\text { Coloured South Africans } \\
\text { Indian South Africans } \\
\text { Chinese South Africans }\end{array} \\
\end{array}$ & \multicolumn{16}{|c|}{ Very low incidence but M.S. occurs in these groups } \\
\hline $\begin{array}{lll}\text { Bantu South Africans } & . . & \end{array}$ & & & & & & & & & & & & & & & & \\
\hline
\end{tabular}


of infancy, probably a virus gastrointestinal infection. Those who escape early infection because of a high level of domestic hygiene may, if they are so predisposed, develop the adult form of the disease when an unstable balance between an allergic and an immune response occurs, responsible for the characteristic exacerbations and remissions of the disease. According to this theory the South African Bantu, Coloured, and Asian living in primitive conditions in a warm country are almost invariably infected in early infancy. It is well established that non-White South African infants have a very high morbidity and mortality from gastrointestinal infections. ${ }^{29}$ A parallel has been drawn between M.S. and poliomyelitis by Poskanzer et al..$^{30}$ In poliomyelitis the paralytic form of the disease occurred most commonly in those with a high level of social hygiene, who therefore were liable to miss an early non-paralytic form of the disease in infancy. ${ }^{31}$ Eadie et al. ${ }^{32}$ claim a correlation between poliomyelitis notification and M.S. incidence with latitude in Australia and New Zealand, but this has been questioned. ${ }^{33}$ Paralytic poliomyelitis in adult South Africans was much more common among the White than among the Coloured, Asian, and Bantu, and in adults at least twice as common among immigrants from the United Kingdom and Europe as among the White South-African-born. ${ }^{34}$

Often the incubation period for virus infection is long-for instance, in the neurological disease scrapie ${ }^{35}$ in sheep and probably in kuru. ${ }^{36}$ Another theory is that M.S. may be an autoimmune reaction to a tissue protein precipitated by immunologically induced damage ${ }^{37}$; any such theory must fit in with the epidemiological facts of the disease.

Among the White population of South Africa the Afrikaansspeaking, the Afrikaners, have on the whole much closer contact with non-Whites, who have a low standard of hygiene, than the English-speaking South-African-born. They usually have close ties with the rural areas and spend some of their time at their own or their relatives' farms, and their children are looked after by Bantu or Coloured servants and very often play with Bantu or Coloured children. On the other hand, the English-speaking South-African-born White population are usually city dwellers and first-generation South Africans, one or both parents having been born in Europe. They usually have smaller families than the Afrikaners and their children have less contact with the non-White population. They are therefore less likely to be infected early in childhood with any possible virus infection than the children of Afrikaans-speaking White South Africans.

Among the White immigrants to South Africa born elsewhere in Africa or born in Southern Europe the prevalence of M.S. is low, as would be expected from this theory. Among immigrants from the United Kingdom the risk of developing M.S. is apparently as high as it is in the United Kingdom. Female immigrants from Northern and Central Europe have also a high prevalence, though, perhaps for social class reasons, the prevalence among male immigrants from Continental Europe is less than is reported in Europe.

The high female:male sex ratio found among the White English-speaking South-African-born M.S. patients may be a significant factor. Male children have more freedom to mix with non-White than female children have.

This theory of an early childhood infection protecting against M.S. would also account for the findings of Kurland et al. in Winnipeg and New Orleans, ${ }^{20}{ }^{21}$ Alter's findings in Israel, ${ }^{19}$ and also for the low prevalence in Japan ${ }^{25}$ and apparently in South America. In Australia, which has a climate similar to that of South Africa, the M.S. rate is apparently fairly high for both the Australian-born and immigrants ${ }^{22-24}$; the Australian-born children do not have servants with a low standard of hygiene. M.S. has not, however, been reported among the Australian aborigines and is apparently uncommon among the Maoris of New Zealand. The theory would also account for the socialclass differences in M.S. rate which have been described..$^{8-10}$

\section{Summary}

No single patient with multiple sclerosis (M.S.) has yet been found among South Africa's 11 million Bantu. The disease does occur among the Coloured and Asian South Africans, but it is very uncommon.

A survey of its annual incidence, prevalence, and annual mortality among the 3 million White population of South Africa is reported. For all White South Africans the average annual incidence was 0.6 per 100,000 . There were 281 White patients with probable M.S. on prevalence day 1960, giving an overall prevalence rate of 9.1 or 11.0 per 100,000 when agecorrected to the population of England and Wales. The annual average mortality in recent years was 0.4 per 100,000 . The female: male sex ratio was higher than has been found in other studies among immigrants from the continent of Europe and among the White English-speaking South-African-born.

The annual incidence, prevalence, and mortality are low for the Afrikaans-speaking White South-African-born, between three and four times higher for the English-speaking White South-African-born, and between 10 and 11 times higher for White immigrants from Central and Northern Europe, including the United Kingdom. These European immigrants had apparently the same risk of developing M.S. as in their country of birth. Immigrants from Southern Europe and White immigrants born elsewhere, usually in other African countries, had a low prevalence of M.S.

There was no significant difference in prevalence for the different groups of White South Africans between the cities, other urban areas and rural areas, nor between the four provinces of South Africa. M.S. occurred more often in two members of a family than would be expected by chance, but it is not clear whether this is because certain families are genetically predisposed to the disease or because members of a family share the same environment.

The steep gradient in the prevalence of M.S. among people of the same European genetic stock in South Africa is evidence that an environmental factor is mainly responsible for M.S. Emigration from a high-risk area to South Africa, a low-risk area, does not apparently lessen the risk of developing the disease. From the present evidence I believe that the gradient of prevalence of M.S. in South Africa, taken in conjunction with the findings of other prevalence surveys elsewhere in the world, strongly suggests that the condition is normally an infection of infancy, probably a virus infection, and that those who are exposed to such living conditions in childhood that they miss early infection may develop multiple sclerosis later in life.

I am particularly indebted to the Medical Directors of the National Multiple Sclerosis Society, New York, Drs. Thomas L. Willmon, and James Q. Simmons, and their neurological advisers Dr. Leonard Kurland, of the Mayo Clinic, and Dr. Donald Acheson, of the Nuffield Department of Clinical Medicine, Oxford, who came to South Africa and gave me great assistance with the methodology of this study. The professors and departments of medicine at the five medical schools and the neurologists and superintendents of the South African hospitals gave me access to their records. I would like to mention especially the late Dr. S. Berman and also Dr. Jim MacGregor, Dr. Harry Reef, Dr. S. Katz, Dr. A. V. Bird, Dr. Annie Theron, Dr. R. W. S. Cheetham, and Dr. T. G. Armstrong, Dr. Andries Blignault, the Editor of the South African Medical Fournal, and Dr. Hillel Shapiro, the Editor of Medical Proceedings, the editors of the main public newspapers, and the South African Broadcasting Corporation. I wish to thank Mr. and Mrs. Cliff Bestall, Mrs. Helen Hollingsworth, and other members of the South African M.S. Society for their hard work on this research. Dr. H. M. Stoker, Director of the Bureau of Statistics and his staff gave me the population statistics, and the Registrar of Deaths provided copies of the M.S. death certificates. Market Research Africa and Mrs. E. Norris carried out the surveys on the populations at risk. I am particularly indebted to Mrs. Isobel 
Henderson, the full-time research secretary of the South African M.S. Society, for her unremitting hard work, and also to Mrs. May Munro and Mrs. Phyllis Basford.

\section{REFERENCES}

' Dean, J. G., Brit. med. F., 1949, 1, 842.

Market Research Africa (Pty.) Ltd. study on birthplace and overseas travel of the White South African population, Johannesburg (1963) and subsequent studies.

- Allison, R. S., and Millar, J. H. D., Ulster med. f., 1954, 23, Suppl. No. 2 .

- McAlpine, D., Lumsden, C. E., and Acheson, E. D., Multiple Sclerosis : A Reappraisal. 1965.' Edinburgh.

- Hargreaves, E. R., Proc. roy. Soc. Med., 1961, 54, 209.

- Pratt, R. T. C., Compston, N. D., and McAlpine, D., Brain, 1951, 74, 191 .

' Dassel, H., Acta psychiat. scand., 1960, 35, Suppl. No. 147, p. 64.

- Registrar-General's Decennial Supplement, England and Wales (1951).

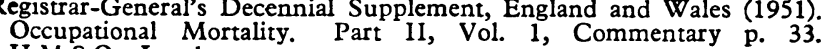
H.M.S.O., London.

- Miller, H., Ridley, A., and Schapira, K., Brit. med. F., 1960, 2, 343.

- Beebe, G. W., Kurtzke, J. F., Kurland, L. T., Auth, T. L., and Nagler, B., American Academy of Neurology meeting, 1966.

12 Hyllested, K., Disseminated Sclerosis in Denmark. Prevalence and Geographical Distribution. 1956. Copenhagen.

12 Acheson, E. D., and Bachrach, C. A., Amer. F. Hyg., 1960, 72, 88

"Swank, R. L., Lerstad, O., Strom, A., and Backer, J., New Engl. \}. Med., 1952, 246, 721 .
14 Wright, K. B., Viviers, G. J., Proctor, N. S. F., Kauffman, J. C. E., and Brüning, E. G. H., S. Afr. med. F., 1965, 39, 386.

is Thomson, J. G., and Ames, F. R., ibid., 1965, 39, 389.

16 Cochrane, J., ibid., 1947, 21, 613.

17 Kramer, S., Lipschitz, R., and Schwartz, M. B., ibid., 1956, 30, 829.

Reef, H., Lipschitz, R., and Block, J., Med. Proc., 1958, 4, 292.

Alter, M., Halpern, L., Kurland, L. T., Bornstein, B., Leibowitz, U., and Silberstein, J., Arch. Neurol. (Chic.), 1962, 7, 253.

${ }_{20}$ Kurland, L. T., Amer. 7. Hyg., 1952, 55, 457

1 Westlund, K. B., and Kurland, L. T., ibid., 1953, 57, 380.

Sutherland, J. M., Tyrer, J. H., and Eadie, M. J., Brain, 1962, 85, 149

Saint, E. G., and Sadka, M., Med. F. Aust., 1962, 2, 249.

Rischbieth, R. H., ibid., 1966, 1, 774.

Okinaka, S., et al., Wid Neurol., 1960, 1, 22.

26 Barlow, J. S., Acta psychiat. Scand., 1960, 35, Suppl. No. 147, p. 108

Swank, R. L., A Biochemical Basis of. Multiple Sclerosis. 1961 Springfield, Illinois.

Campbell, A. M. G., Daniel, P., Porter, R. J., Russell, W. R., Smith,

H. V., and Innes, J. R. M., Brain, 1947, 70, 50.

29 Dean, J. G., S. Afr. med. F., 1965, 39, Suppl. July.

so Poskanzer, D. C., Schapira, K., and Miller, H., Lancet, 1963, 2, 917

31 Gear, J. H. S., Wld Hlth Org. Monogr. Ser., 1955, No. 26, p. 31.

Eadie, M. J., Sutherland, J. M., and Tyrer, J. H., Brit. med. f., 1965 1,1471 .

33 Kurtze, J. F., ibid., 1965, 2, 1308.

34 Dean, J. G., S. Afr. med. Ұ., 1967, 41, 294.

ss Stamp, J. T., Vet. Rec., 1962, 74, 357.

s6 Gajdusek, D. C., Gibbs, C. J., jun., and Alpers, M., Nature (Lond.), 1966, 209, 794.

${ }^{7}$ Mackay, I. R., and Burnet, F. Macfarlane. Auto-immune Diseases. Pathogenesis, Chemistry and Therapy. 1963. Springfield, Illinois.

\title{
Daily Progestogen for Contraception : a Clinical Study
}

\author{
J. MARTINEZ-MANAUTOU,* M.D. ; J. GINER-VELASQUEZ, $\dagger$ M.D. ; V. CORTES-GALLEGOS, $\dagger$ M.D.

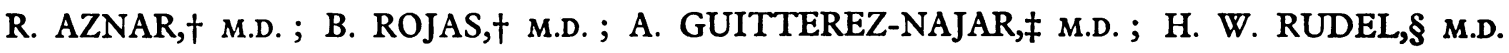

Brit. med. 9.. 1967, 2, 730-732

The principal technique of hormonal methods of contraception, based on original studies by Pincus et al. (1958), has relied on the joint action of an oestrogen (mestranol) and a progestogen (norethynodrel) given cyclically for 20 days monthly. Combinations of other progestogens with either mestranol or ethinyloestradiol have also been studied. The biological and clinical basis of the antifertility effects of these agents were reviewed by Diczfalusy (1965) and by Rudel and Kincl (1966). The contraceptive mechanisms were described as (1) inhibition of ovulation, by both the oestrogen and the progestogen; and, from the anti-oestrogenic action of the progestogen, (2) a suppressed endometrium unfavourable to nidation, with (3) a cervical mucus hostile to spermatozoal motility. Definitive data on human tubal physiology relating to these agents have not been reported. Mestranol or ethinyloestradiol, given early and with regularity before ovulation, consistently inhibits its occurrence (Rudel and Martinez-Manautou, 1964 ; MartinezManautou and Rudel, 1966). Similar observations were made for ethinyloestradiol by Greenblatt et al. (1954). Thus, with the anti-ovulatory role of oestrogen and the anti-oestrogenic effects of progestogen defined, the concept of sequential therapy evolved-that is, early oestrogen for inhibition of ovulation, and later oestrogen plus progestogen to promote maturation of the endometrium with regular withdrawal bleeding. Oestrogen and progestogen, used concomitantly or sequentially, suppress the hypothalamic-pituitary-gonadal cycle, thus preventing ovulation and the normal endogenous regulation of the uterine bleeding cycle.

On evaluating the contraceptive potential of the progestogen chlormadinone acetate in a daily dosage range of $0.5 \mathrm{mg}$. to $\&$ mg., a sensitivity differential was found between dosage and

- Seguro Social, Mexico, D.F.

† Centro de Investigacion de Fertilidad y Esteriledad, Mexico, D.F.

Hospital de la Mujer, Mexico, D.F.

The Population Council, Bio-Medical Division, Rockefeller University, N.Y. the development and degree of (1) inhibition of cervical mucus fluidity, (2) suppression of the endometrium, and (3) inhibition of ovulation (Rudel, 1964 ; Rudel et al., 1965, 1967 ; MartinezManautou and Rudel, 1967). Within this range the highest doses produced all three effects, whereas on reducing the dosage to $0.5 \mathrm{mg}$. only inhibition of the cervical mucus was uniformly maintained; there was some endometrial suppression and, to a lesser degree, inhibition of ovulation. Though, originally, small numbers of women were studied, no pregrancies were seen with chlormadinone acetate $0.5 \mathrm{mg}$. daily. This suggested a method in which progestogen given uninterruptedly in small daily doses produces contraception without inhibiting ovulation, and if the pituitary-gonadal axis is not interrupted normal menstruation would occur.

Prompted by these observations, Martinez-Manautou et al. (1966) carried out a clinical study to define the contraceptive effectiveness of a continuous daily dose of chlormadinone acetate $0.5 \mathrm{mg}$. Three hundred and twenty women were observed for 1,214 cycles, and two pregnancies were reportedone, as a failure of the method. Approximately $60 \%$ of the group had cycles ranging between 24 and 34 days. Because of the simplicity and acceptability, as well as effectiveness, of the method, these studies were extended, and the results are the subject of this paper. Since there is a possibility of lactating mothers becoming pregnant, nursing mothers were admitted to the programme.

\section{Material and Methods}

Chlormadinone acetate $0.5 \mathrm{mg}$. daily was given continuously to two groups of fertile women. Group 1 comprised 945 nonlactating regularly menstruating women under 36 years of age, and group 2 comprised 100 lactating women, varying from 1 to 15 months post partum. Each received a thorough gynaecological examination, with a Papanicolaou smear, the latter 